\title{
Kamu Yönetiminde Siyasallaşma ve Kayırmacılık Sorununa Ahlak ve Adalet Eksenli Çözüm Önerileri ${ }^{1 *}$
}

\author{
Ömer ÇAMUR \\ Dr. Öğr. Üyesi, Bingöl Üniversitesi, \\ Sağlık Hizmetleri Meslek Yüksekokulu, Yönetim ve Organizasyon Bölümü \\ ocamur@bingol.edu.tr \\ Orcid ID: https://orcid.org/0000-0001-6447-1475
}

\author{
Ahmet Hamdi AYDIN \\ Prof. Dr., Emekli Öğretim Üyesi \\ ahaydin@ksu.edu.tr \\ Orcid ID: https://orcid.org/0000-0002-1886-7951
}

\begin{abstract}
Öz
Siyasallaşma, yönetim ile siyaset arasındaki ilişkilerin kuvvetli olması ile ortaya çıan temel yönetsel sorunlardan biridir. Siyasallaşan bir yönetimde en genel hali yönetim siyasi davranışlarda bulunmakta veya siyasi iktidarın gölgesinde faaliyet göstermektedir. Kayırmacılık ise kendi başına yönetsel bir sorun olmakla birlikte siyasallaşma ile daha da belirginleşen kamu yönetiminin önemli sorunlarından bir diğeridir. Kayırmacıllğın yaşandığı bir yönetimde liyakat ilkesi başta olmak üzere birçok yönetsel değer uygulama alanı bulamamakta ve kamu yönetimi kendisinden beklenen görevleri yerine getirememektedir. Dolayısıyla siyasallaşma ve kayırmacılık, kamu yönetimi için kesinlikle giderilmesi gereken önemli bir sorundur. $\mathrm{Bu}$ sorunun giderilebilmesinde ahlak ve adalet oldukça etkilidir. Zira ahlak ve adalet, kamu yönetiminin verimli kılınabilmesi için gerekli olan tüm değerlerin yönetimde var olmasının sağlanmasından yönetimin amacı doğrultusunda faaliyet göstermesine kadar etkili olan temel olgulardır. Ahlak ve adaletin gözetilmediği bir kamu yönetiminde, en genel hali ile hak kavramı zayi olmakta, başta siyasallaşma ve kayırmacılık olmak üzere birçok yönetsel sorun baş göstermekte ve halkın
\end{abstract}

\footnotetext{
${ }^{1}$ Makale Geliș/Kabul Tarihi: 12.10.2019 / 29.07.2021

* Bu çalışma Kahramanmaraş Sütçü İmam Üniversitesi Sosyal Bilimler Enstitüsü Kamu Yönetimi Ana Bilim Dalı'nda Prof. Dr. Ahmet Hamdi AYDIN danışmanlığında Ömer ÇAMUR tarafından 2019 yılında tamamlanan "Türkiye'de Kamu Yönetimi İle İlgili Sorunların Çözümünde Ahlak ve Adaletin Rolü” başlıklı doktora tezinden üretilmiştir. Künye Bilgisi: Çamur, Ö. ve Aydın, A. H. (2021). Kamu yönetiminde siyasallaşma ve kayırmacılık sorununa ahlak ve adalet eksenli çözüm önerileri. Kahramanmaraş Sütçü Imam Üniversitesi Sosyal Bilimler Dergisi, 18(2), 1140-1166. DOI: 10.33437/ksusbd.645929.
} 
ihtiyaçları karşılanamamaktadır. Yapılan bu çalışmada öncelikle siyasallaşma ve kayırmacılığın ne olduğu açıklanacaktır. Çalışmanın devamında Türk kamu yönetiminde siyasallaşma ve kayırmacılığın nasıl sorun olduğu ortaya konacaktır. Çalışmanın sonucunda ise Türk kamu yönetiminde siyasallaşma ve kayırmacılık sorununun giderilebilmesi için ahlak ve adalet temelinde öneriler geliştirilecektir.

Anahtar Kelimeler: Siyasallaşma, Kayırmacılık, Ahlak, Adalet.

\title{
Ethics and Justice Oriented Solutions to the Problem of Politicization and Favoritism in Public Administration
}

\begin{abstract}
Politicization is one of the primary administrative problems arising from the existence of excessive relationships between administration and politics. In a politicized administration in the most general sense, administration displays political behaviors or acts under the shadow of political power. While favoritism is an administrative problem in itself, it is also among the primary problems of public administration that become more apparent with politicization. In an administration with practices of favoritism, many administrative values and the principle of merit in particular cannot be applied, and public administration fails to perform duties expected of it. Thus, politicization and favoritism constitute a major problem for public administration that must be overcome. Ethics and justice play a significant role in solving this problem, because ethics and justice are fundamental phenomena that have impact on from a range of issues ensuring that administration has all the values required for making public administration effective to the acting of administration in accordance with its purpose. In a public administration not safeguarding ethics and justice, the concept of right in its broadest sense gets lost; many administrative problems, politicization and favoritism in particular, arise, and the needs of the public are not satisfied. This study first defines the concepts of politicization and favoritism, and reveals how politicization and favoritism have become a problem in Turkish public administration. Then, it proposes solutions based on ethics and justice to overcome the problem of politicization and favoritism in Turkish public administration.
\end{abstract}

Keywords: Politicization, Favoritism, Ethics, Justice. 


\section{GİRIŞ}

Kamu yönetimi, insanların ortak ihtiyaçlarını gidermek amacıyla oluşturdukları ve tarihin ilk yıllarından beri var olan temel yönetsel bir olgudur. Temel amacı vatandaşlara yararlı olmak olan kamu yönetimi, halkın beklediği mal ve hizmetlerin üretimidir. Kamu yönetiminin kendisinden beklenen hizmetleri etkili ve verimli bir şekilde yerine getirebilmesi, onun sorunsuz bir şekilde işlemesi ile mümkündür.

Siyasallaşma yönetim ile siyaset arasındaki ilişkilerin net olmamasından kaynaklanan bir sorun olarak ortaya çıkmaktadır. Birçok yönetsel sorunu beraberinde getiren siyasallaşmanın en önemli sonucu ise kayırmacılıktır. Siyasallaşma ve kayırmacılık sorunu, kamu yönetiminin amacı doğrultusunda faaliyet göstermesini engelleyen temel yönetsel sorunlardan biridir.

Yönetim ile siyaset arasında tarihsel bir ilişki bulunmaktadır. Öyle ki kamu yönetimi modern çağda siyaset biliminden ayrılarak bir bilim dalı olmuştur. $\mathrm{Bu}$ durum yönetim ile siyaset arasındaki kaçınılmaz bir ilişkinin varlığını zorunlu kılmaktadır. Esasen devlet tüm kurumları ile bir bütündür ve her aşamada yönetsel ilişkilerin varlığı bir gerekliliktir. Siyasallaşmada temel problem, yönetim ile siyaset arasındaki ilişkilerin olması gerekenden daha kuvvetli olmasından kaynaklanmaktadır. Böylesi bir durum siyasetin yönetim üzerinde otorite kurmasına ve yönetimin siyasi otoritelerin istekleri doğrultusunda hareket etmesine neden olmaktadir.

Siyaset ile yönetim arasında bir ilişkinin varlığı normaldir ve kaçınılmazdır. $\mathrm{Bu}$ ilişkideki temel problem siyasetin yönetim üzerindeki otoritesinin kullanılma tarzında yaşanmaktadır. Sonuç itibariyle siyasallaşma ve kayırmacılık kamu yönetiminin amacı doğrultusunda faaliyet göstermesi için giderilmesi oldukça önemli olan bir sorundur. Bu sorunun giderilebilmesiyle ahlak ve adaletin yakından ilişkili olduğu düşünülmektedir. Zira ahlak ve adalet, tüm tarihsel dönemlerde yönetsel sorunların giderilmesinde ve verimli bir kamu yönetiminin inşasında yegane unsurlar olarak ön plana çıkmışlardır.

Temelde en iyi yaşama biçiminin oluşturulmasını amaçlayan ahlak, bu amaç doğrultusunda insanlara neyin iyi ve doğru, neyin kötü ve yanlış olduğunu gösteren kurallar bütünüdür. Bireysel anlamda en yüksek iyiye ulaşmak suretiyle ideal bir insan oluşturma üzerine odaklanan ahlak, toplumsal ve yönetsel sistemlerin de en yüksek iyiye ulaşmalarının anahtarıdır. Zira toplum veya tüm yönetimler, tıpkı bir insan gibi, şahsiyet olarak meydana gelmekte ve bireysel değerlerle şekillenmektedir.

Erdemlerin erdemi olarak betimlenen adalet ise, temelde hak kavramı ile belirginleşmektedir. $\mathrm{Bu}$ doğrultuda adalet, en genel hali ile her insana hak 
ettiğinin verilmesidir. Adalet, her şeyin olması gereken yerde olmasıdır. Yine adalet, her şeyin doğasının gerektiği şekliyle olmasıdır. Geniş bir kavram olması nedeniyle farklı görünümlere sahip olan adalet yönetsel açıdan incelendiğinde devlet yönetiminin temelidir. Bu durum devletin tüm kurumları için geçerli olduğu gibi kamu yönetimi için de geçerlidir. Adaletin dikkate alınmadığ 1 yönetimlerde hak kavramının zayi edilmesi ve dolayısıyla kamu yönetiminin doğasına uygun olmayan uygulamaların baş göstermesi, birçok sorunun ortaya çıkmasına neden olmaktadır.

Yapılan bu çalışmada öncelikle siyasallaşma ve kayırmacılık kavramlarının ne anlama geldikleri detaylı bir şekilde incelenecektir. Çalışmanın devamında öncelikle Türk kamu yönetiminde siyasallaşmanın öne çıkan bir sorun olduğu ortaya konacak ve bu sorunun giderilebilmesi için ahlak ve adalet temelli çözüm önerileri geliştirilecektir. Çalışmanın son bölümünde Türk kamu yönetiminde etik kültürün oluşması için kurulan Kamu Görevlileri Etik Kurulunun siyasallaşma ve kayırmacılık sorununu gidermedeki rolü incelenecektir.

\section{SIYYASALLAŞMA VE KAYIRMACILIK}

Siyasallaşma yönetim ile siyaset arasındaki ilişki sonucu ortaya çıkan kamu yönetiminin önemli sorunlarından biridir. Kayırmacılık ise kendi başına bir yönetsel bir yozlaşma türü olmasına rağmen siyasallaşma ile belirginleşen bir kavramdır. Esasen her iki kavram da bürokrasi ve siyaset arasındaki ilişkiler sonucu ortaya çımakta ve kamu yönetimi açısından birer sorun halini almaktadırlar. Bu durum kamu yönetiminin farklı alanlarla olan ilişkisinden kaynaklanmaktadır. Disiplinler arası bir nitelik sergileyen kamu yönetimi, tarihsel süreç içerisinde, siyaset biliminden ayrılarak bir bilim dalı haline gelmiştir (Saklı, 2011: 99). Bu nedenle siyaset ile kamu yönetimi arasında tarihsel bir ilişkinin varlığ kaçınılmaz olmaktadır.

Klasik yönetim anlayışına göre kamu yönetimi, siyasi mekanizmaların almış olduğu kararları uygulamakla yükümlü bir yapıyı ifade etmektedir. Yine kamu yönetiminin almış olduğu kararlardan ve faaliyetlerinden dolayı siyasal iktidara karşı sorumlu olması, kamu yönetimi ile siyaset arasındaki ilişkiyi güçlendirmektedir. Özellikle kamu yönetiminde hiyerarşik düzende yukarı doğru çıkıldıkça bürokrasi ile siyaset arasında kesin bir ayrım yapmak daha da zor olmaktadır. $\mathrm{Bu}$ nedenle bürokrasi ile siyaset arasında kesin bir çizginin var olduğunu söylemek mümkün değildir (Gökçe vd., 2002: 46-51).

Bürokrasi ile siyaset birbirleri ile yakından ilişkili olmanın yanı sıra ve bazen de birbirlerini etkileyen kavramlardır. Yani bazen bürokrasi siyasileşebildiği gibi, siyaset de bürokratikleşebilmektedir (Gökçe vd., 2002: 46). Günümüzde bürokrasinin sahip olduğu profesyonellik, uzmanlık, istikrarlı bir statü, bilgi, kurumsal bir dayanışma, meslek ve kurum ideolojisi gibi birçok faktör nedeniyle, 
bürokrasi zaman zaman siyasi temsilcileri etkileyen, onların iradesi dışına çıkan, sabote eden ve onlarla otorite mücadelesi içine giren kamusal bir iktidar gücü kazanabilmektedir (Ery1lmaz, 1997: 1356).

Kamusal nitelikteki örgütler toplumsal içerikli hizmetlerin rasyonel bir şekilde yürütüldüğ̈̈ yönetim birimleridir. Bürokrasi olarak tanımlayabileceğimiz bu yönetim birimi, değişen siyasal iktidarlar aracıllğıyla rasyonel bir şekilde hizmet üretmektedirler. Hizmet üretim sürecinde kamu görevlilerinden tarafsız ve siyasi iktidarın esiri olmadan görev yapmaları beklenmektedir. Kamu personelinin rasyonellikten uzaklaşması ve kamu kurumlarının siyasi parti organı gibi faaliyette bulunmaları siyasallaşmaya neden olmaktadır. Kamu yönetiminin toplumsal çıkar düşüncesinden uzaklaşması ise siyasallaşma oranını göstermektedir (Dinçer, 1997: 1112).

Bürokrasi ve siyaset arasında yaşanan ilişki boyutunun aşırı olması siyasallaşma olarak ifade edilmektedir. Kelime anlamı ile siyasallaşma, "siyasete ait olma, siyasetle ilgili hale getirme" anlamına gelmektedir. Bu yönü ile siyasallaşma, herhangi bir düşünce ya da olgunun siyasi bir içerik taşımasıdır (Dinçer, 1997: 1112). Daha çok gelişmekte olan ülkelerde görülen bir sorun olarak siyasallaşma, kamu hizmetlerine giriş ve kamu yönetimine yapılan atamalarda siyasi faktörlerin birinci derecede rol oynamasıdır. Siyasallaşma, her iktidarın farklı bir personel politikası izlemesi ve liyakate bakmadan personel atamalarını kendi siyasal tercihlerine göre yapmaları anlamına gelmektedir. Başka bir tanıma göre ise siyasallaşma, kamu yönetimine parti politikalarının egemen olmasını ve iktidarda bulunan partinin kendi çıkarlarını, toplumsal çıarlardan önce görmesini ifade etmektedir (Eryılmaz, 2015: 305; Aydın, 2017: 281; Tutum, 1976: 11).

Kayırmacılık ise, iltimas veya günlük dilde torpil diye adlandırılabilmektedir (Özkanan ve Erdem, 2014: 186). Kayırmacılık, kamu yönetiminde maddi çıkar sağlamaktan ziyade bazı kimselere bağl1lıklar ve yükümlülükler nedeniyle ayrıcalık tanınması anlamına gelmektedir. Başka bir ifade ile kayırmacılık, iktidar sahiplerinin, makam ve mevki sahibi kişilerin, makamlarından kaynaklanan imkanlarla, gerek siyasi ideoloji ve gerekse kan bağ 1 veya özel bir bağ sebebiyle kendilerine yakın olan kişilere maddi veya manevi çıkar sağlayacak şekilde davranmalarıdır (Berkman, 2009: 31; Özer, 2000: 91).

Kayırmacılık, yakınları kayırma ve siyasal kayırmacılık olmak üzere iki şekilde ortaya çıkmaktadır. Yakınları kayırma, kamu görevine yapılan atamalarda liyakat yerine akraba, eş-dost, hemşehri veya siyasal yakınlık gibi nedenlerin birinci derecede rol oynaması ile ortaya çıkmaktadır. Kamu personeli akrabalık ve yakınlık ilişkileri nedeniyle kendisini yükümlülük altında hissedebilmekte ve yakınlarına farklı davranabilmektedir (Eryılmaz, 2015: 306; Y1lmaz ve Klavuz, 
2002: 25). Yakınları kayırma akraba kayırmacıllğı (nepotizm) ve eş-dost kayırmacılığ 1 (kronizm) olmak üzere ikiye ayrılmaktadır. Nepotizm, kamu personelinin kendi otoritesini ve gücünü kullanarak kendi aile fertlerini ve akrabalarını liyakatlerine bakmaksızın kamuda istihdam olanağ 1 sağlaması anlamına gelmektedir (Karakuş ve Çak, 2007: 78). Nepotizm daha çok geleneksel ilişkilerin ve bağların yoğun bir şekilde yaşandığı az gelişmiş ülkelerde yaygın bir şekilde görülmektedir. Bazı yazarlar nepotizmde kamu personelinin bir çıkarının olmadığını ileri sürmekteyken bazı yazarlar ise kamu görevlisinin manevi bir kazanç elde ettiğini ileri sürmektedirler. Yani takdir edilme veya itibar görme gibi psikolojik bazı kazanımların elde edildiği düşünülmektedir. Kronizm ise, mevcut otoritenin veya kamu yöneticisinin kendi imkan ve olanaklarını kullanarak akraba ve yakınlardan ziyade, eş-dost taraflarına işe girmede ve yükselmede imkan sağlamaları anlamına gelmektedir. Türkiye'de yaygın bir şekilde görülen hemşehri kayırmacıllğ (Fındıkçı, 2013: 63; Özsemerci, 2003: 20-21).

Bir diğer önemli kayırmacılık türü olan siyasal kayırmacılık ise, "siyasal partilerin iktidara geldikten sonra kendilerini desteklemiş olan seçmen gruplarına çeşitli şekillerde ayrıcalıklı davranarak bu kişilere haksız menfaat sağlamaları" şeklinde tanımlanmaktadır (Fındıkçı, 2013: 76). Yani siyasal kayırmacılık, siyasal iktidarın yandaşlarını seçim döneminde bulundukları yardımlardan dolayı ödüllendirmeleri anlamına gelmektedir. Siyasi partilerin iktidara geldikten sonra kamu yönetimi içerisinde üst düzey çalışanları görevden almaları ve bu görevlere siyasal yandaşlık ya da siyasal ideoloji gibi faktörlerle yeni kimseler atamaları da mümkün olmaktadır. Siyasal kayırmacılığın farklı bir görünümü olan bu duruma literatürde patronaj adı verilmektedir. Siyasal kayırmacılık ile patronaj kamu yönetiminin siyasallaşması ile ortaya çıkan önemli yozlaşma türlerindendir (Aktan, 2001: 58).

Siyasal kayırmacılık sadece kamu yönetimine yapılan atamalarda ve yükselmelerde değil, aynı zamanda kamu yönetimi eliyle halka sunulan hizmetlerde de ortaya çıkmaktadır. Hizmet kayırmacılı̆̆ 1 olarak adlandırılan bu durum, siyasal iktidarın diğer seçimlerde de iktidarda kalabilmek amaciyla kamusal gelirleri oylarını maksimum düzeye çıkaracak şekilde seçim bölgelerine ayırması ve kamusal kaynakların yağmalanmasıdır. Hizmet kayırmacılığı, kamusal kaynakların dağıtımında halkın ihtiyaçlarının dikkate alınmaması ve siyasi iktidarın gerekli hizmetleri kendi seçim bölgesine götürmesidir (Özsemerci, 2003: 21).

Siyasal kayırmacılık geniş bir kavram olarak nepotizm ve kronizmi de kapsayan önemli bir olgudur. Yani siyasal kayırmacılığın yaşandığı bir ülkede siyasal iktidar eliyle hem akraba ve yakınlar hem de eş-dost kayırmacılı̆̆ına rastlanabilmektedir. 
Bu bilgiler ışığında çalışmanın bir sonraki başlığında Türk kamu yönetiminde bir sorun olarak siyasallaşma ve kayırmacılık konusuna değinilecek ve sorunun Türkiye'deki boyutu ortaya konmaya çalışılacaktır.

\section{KAMU YÖNETIMINDE SIYYASALLAŞMA VE KAYIRMACILIK SORUNU}

Kamu yönetimi ile siyaset arasındaki kaçınılmaz ilişki sonucu ortaya çıkan siyasallaşmanın asıl nedeni, bürokrasi ile siyaset arasındaki ilişkinin aşırı bir seviyede olması ve bürokrasinin siyasetten bağımsız hareket etmesinin ortadan kalkmasında yaşanmaktadır. Yazıcıoğlu'nun da belirttiği üzere Türkiye'de siyasallaşma olgusu, kamu yönetimi ile bürokrasinin yerlerinin belli olmamasından kaynaklanmaktadır. Zira ne bürokratlar ne de politikacılar olması gereken yerde değildirler ve hatta en olmamaları gereken yerdedirler. Siyasi iktidarın idari yapının dışında kalması sonucu kendisini etkisiz, yetkisiz ve işlevsiz olarak görmesi, onun kamu yönetimine fiili müdahaleler ile bu durumu değiştirme isteğine neden olmakta ve kamusal çıkarlar yerine siyasal çıkarları ön plana çıkmaktadır. Asıl sorun ise burada yaşanmaktadır (1997: 261).

Tarihsel olarak incelendiğinde Türkiye'de siyasal partiler iktidara geldikten sonra kamu yönetimini politize etme yoluna gitmişlerdir. Siyasal iktidarlar politikalarını etkili, verimli ve hızlı bir şekilde kısa süre içerisinde uygulayabilmek için siyasallaşmayı temel bir çözüm yolu olarak görmüşlerdir. Bu nedenle kamu yönetiminin yüksek mevkilerine yapılan atamalar genellikle siyasal iktidarın takdiri ile gerçekleşmiştir. Hatta bu atamalar hiyerarşi içerisinde aşağı seviyelere kadar inmiştir (İzci ve Bozdoğan, 2016: 42). Bunu yaparken de siyasallaşmayı kolay kılmak için yeni kadrolar ve makamlar açma yoluna gidilmiştir. Türkiye'nin hali hazırdaki personel sisteminde bir memurun görevden alınmasının zor olması nedeniyle görevden alma yerine özlük haklarına uygun olan çok sayıda özellikle de üst düzey kadrolar açılmıştır (Eryılmaz, 2015: 306).

Türkiye'de 657 sayılı Devlet Memurları Kanununa göre, "devlet memurları siyasi partiye üye olamazlar, herhangi bir siyasi parti, kişi veya zümrenin yararını veya zararını hedef tutan bir davranışta bulunamazlar; görevlerini yerine getirirlerken dil, ırk, cinsiyet, siyasi düşünce, felsefi inanç, din ve mezhep gibi ayrım yapamazlar; hiçbir şekilde siyasi ve ideolojik amaçlı beyanda ve eylemde bulunamazlar ve bu eylemlere katılamazlar." Yine Kamu Görevlileri Etik Davranıș İlkeleri ile Başvuru Usul ve Esasları Hakkında Yönetmelikte kamu görevlilerinin siyasi düşünceden dolayı ayrım yapamayacakları, görevlerini siyasal parti çıkarları için kullanamayacakları, siyasal partileri menfaat ve kayırmacılık amacıyla kullanamayacakları belirtilmiş̧tir. Görüldüğü üzere Türkiye'de kamu personelinin siyasal eylemlerde bulunması yasaklanmıştır. 
Lakin uygulamada buna riayet edilmediği görülmekte ve kamu yönetiminin siyasallaşmasına neden olunmaktadır.

Türk kamu yönetimi personel rejimi geleneksel olarak kariyer ilkesi üzerinde yükselmektedir. Türk kamu personel sistemi kariyer ilkesi ile liyakat ilkesini bir arada benimsemiştir. Diğer bir ifade ile daha üst basamaklara yükselebilmenin diğer bir koşulu, o basamakların gerektirdiği liyakate sahip olmaktır. Mevzuatta liyakat ve kariyer ilkeleri benimsenmiş olmasına rağmen, uygulamada genellikle yeteneğe bakılmaksızın üst basamaklara çıkılabilme şeklindeki uygulamalara denk gelinebilmektedir. Yine özellikle atamalarda siyasi iktidarların etkisiyle de bu ilkeler göz ardı edilebilmektedir (Güler, 2013: 193; Şaylan, 2000: 134). Bu durum yeni seçilen yöneticilerin üst kademeleri değiştirirken çalışabileceği insanları üst görevlere ataması hususunda normal karşılanabilir. Fakat yapılan aramalarda liyakatin göz ardı edilmesi yönetimin kayırmacılık çıkmazına girmesine neden olmaktadır.

Türk kamu yönetiminde kayırmacılık problemi henüz işe alım aşamasında başlamakta ve mesleki kariyer içerisinde varlığını devam etmektedir. Kayırmacılığın engellenebilmesi amacıyla Türkiye'de kamu görevine girişte sınav sistemi uygulanmaya başlanmıştır. Eryılmaz'a göre Türkiye'de 1999 yilından itibaren uygulanan merkezi sinavlar ile bilgisayar ortamında yapılan atamaların kayırmacılık sorununun giderilmesine önemli katkılarının olduğu söylenebilir. Yine de kayırmacılığın hakim olduğu alanlarda yapılan sınavların çoğu bir formalite olmaktan öteye geçmemektedir. Özellikle yazılı sınavların objektif bağlandığı durumlarda, ikinci aşamada sözlü sınavlar varsa, bu aşamada kayırmacılık yapılabilmektedir (2015: 306).

Türk kamu yönetiminde siyasallaşma ve kayırmacılığın birçok nedeni bulunmaktadır. Öncelikle siyasal iktidarlar, kendi politikalarını etkin ve verimli bir şekilde yürütebilmek amaciyla bürokrasi üzerinde hakimiyet kurmaya çalışmaktadırlar. Bürokratik yapının, siyasal iktidarlar tarafından sürekli bir şekilde kontrol edilmeye çalışılması, gücünün zayıflatılarak iktidar amaçları için çalışan bir duruma getirilmek istenmesi ve sürekli olarak siyasal etkiye maruz kalması siyasallaşmaya neden olmaktadır (Yılmaz ve Klavuz, 2002: 19).

Siyasal partiler iktidarı elde edebilmek amacıyla halka çeşitli vaatlerde bulunmakta ve iktidara geldikten sonra ise bu vaatleri yerine getirebilmek için kamu yönetimi içerisinde uzun yıllar çalışmış ve uzmanlaşmış kamu yöneticilerinden yardım ve destek beklemektedirler. Bu noktada yönetimin gerekleriyle siyasilerin istekleri arasında bir uyuşmazlık çıktığında, yönetimden kaynaklanabilecek direnmenin kırılabilmesi için siyasal iktidar kendisine yakın olan kişileri yüksek yönetsel basamaklara atama eğilimi içerisinde girmektedir. $\mathrm{Bu}$ durum özellikle üst yönetim ile siyasetin iç içe geçmiş gibi görünmesine 
neden olmaktadır. Böylesi bir ortamda siyasallaşmanın boyutu ise bazen yoğunlaşmakta ve alt basamaklara kadar varabilmektedir. Bunun sonucunda siyasallaşan bir yönetim kamuya hizmet etmekten çok, siyasal otoriteye hizmet etmeye başlamaktadır. Gelinen nokta kamu görevinin anlamını yitirmesine ve halk adına faaliyet göstermesi gereken kamu yönetiminin belli çıkarlara hizmet etmesine neden olmaktadır (Ergun, 2015: 295-296).

Kamu yönetimi, kamusal politikaların formüle edilmesi ve uygulanmasında siyasi iktidara daima bir şekilde bağımlı bulunmaktadır. Aslında demokratik yönetim sisteminin benimsendiği bir ülkede seçilmişlerin atanmışlardan üstün tutulması olağan bir durumdur. Ancak bu bağımlılık, Türkiye'de siyasi yöneticilerin bürokratlar üzerinde güçlü kontrolü ile sonuçlanmıştır. Bürokratlar siyasi efendileri memnun kaldıkları sürece makamlarında kalabilmektedirler. Öyle ki bürokratlar, kamusal politikaların uygulanmasında yapabileceklerinin en iyisini yapsalar dahi, bu yapılan eğer siyasi otoritenin veya iktidar partisinin geleceğini tehdit eden bir çaba olarak görülürse, bürokratlar görevden alınmakta veya başka daha az aktif bir yere getirilmektedirler. Bu durum bürokratlarda kamu politikalarına ve uygulamalarına karşı bir ilgisizliğe ve dolayısıyla kamu yönetimi uygulamaları üzerinde başarısız bir etkiye neden olabilmektedir (Çevik, 2012: 189-190).

Kamu yönetimi, demokratik ülkelerde yürütme organının emrinde bulunan, onun politikalarını ve yasaları uygulamakla görevli olan araçsal nitelikte yönetsel bir aygıttır. Teorik anlamda kamu yönetiminin görevi, kamu hizmetlerinin yürütülmesi, kuralların ve kamusal politikaların uygulanması ve her siyasal iktidara karşı eşit mesafede durularak onlara uzmanlık bilgisinin sunulmasıdır. Ancak bürokrasinin uzmanlık ve deneyiminin siyasal iktidarlar ile eşit ölçüde paylaşılmadığı durumlarda siyasal iktidarlar bürokrasinin sadakatinden emin olmak istemekte ve göreve geldiklerinde üst düzey yöneticileri değiştirme eğilimi göstermektedirler. İktidardaki siyasi partinin sadakatten çok liyakate önem vermesi sonucunda ise bürokrat değişimleri olmamakta veya çok sınırlı sayıda değişim yaşanmaktadır. Türkiye'de ise siyasal iktidarlar liyakatten çok sadakate önem vermekte ve kamu yönetiminin siyasallaşmasına neden olmaktadırlar (Eryılmaz, 2007: 247-253).

Kamu yönetiminin siyasallaşması, siyasal partilerin bürokrasiyi etkilemeleri ve partilerin kendi çıkarları doğrultusunda ulusal politikaların aleyhine kararlar alması hususlarında ortaya çıkmaktadır. Bu durum siyasallaşmanın kamu yönetimi açısından iki farklı şekilde tezahür ettiğini göstermektedir. $\mathrm{Bu}$ unsurlardan birinde kamu yönetiminde yapılan atamalarda siyasal amaçlar ve parti düşüncesi ortaya çıkarken, diğerinde ise, kamu personelinin siyasi faaliyette bulunma özgürlüğünün derecesi ve bu konu ile ilgili olarak siyasal iktidarın tutumudur. Bu nedenle kamu yönetiminde ortaya çıkan siyasallaşma, hükümetin 
izlediği kamu personel politikası ile somutlaşmaktadır (Gökçe ve Şahin, 2002: 17).

Kamu yönetiminde siyasallaşmayı ve özellikle kayırmacılığı engelleyebilmek için gerekli olan en etkili yöntem personel yönetiminde liyakat ilkesinin benimsenmesi ve kamu yönetimine egemen kılınmasıdır (Özsemerci, 2003: 45). Liyakatsizlik sorunu, kamu yönetiminde siyasallaşma ile birlikte daha da belirginleşmektedir. Liyakat ilkesi, vatandaşların kamu görevine girişlerinde ve çalışmaları sırasında karşılaşacakları bütün işlemlerde kişisel ve keyfi takdirden, siyasal müdahalelerden uzak, sadece hizmetlerin niteliklerine uygun olarak objektif usullere göre değerlendirilmesini gerekli kılmaktadır. Yani liyakat ilkesi, bireylerin siyasal parti veya iktidara yakınlıklarına göre değil, yetenek ve bilgisine göre devlet memuru olabilmeleri ve kariyerlerinde bu durumun gözetilmesini ifade etmektedir (Uz, 2011: 78). Türk kamu yönetiminde liyakat sisteminin etkin bir şekilde işletilememesinden dolayı ortaya çıkan kayırmacılık, kamu yönetimi için yeni bir durum değildir. Tarihsel süreç olarak incelendiğinde Osmanlı Devletinden günümüze varlığını devam ettiren bir sorun olarak karşımıza çıkmaktadır. Özellikle Osmanlı Devletinin son yıllarında ülkenin içinde bulunduğu olumsuz durumdan dolayı önlenemeyen kayırmacılık sorunu, Cumhuriyetin ilanından sonra da varlığını devam ettirmiştir. Cumhuriyetin ilanından sonra tek parti döneminde memurların atanmaları ve yükselmeleri ile ilgili işlemlerin siyasi parti eliyle yürütülmesi, liyakat ilkesi yerine partiye bağlılığın ve sadakatin ön planda tutulması kayırmacılık sorununun varlığını siyasallaşma temelinde sürdürmesine neden olmuştur. Takip eden yıllarda özellikle 657 sayı1ı Devlet Memurları Kanununun çıkarılması ve kamu personel sistemi ile ilgili diğer yasal düzenlemelere rağmen kayırmacılık varlı̆̆ını devam ettiren önemli bir sorundur. Gelinen noktada Türkiye'deki anayasa ve kanunlar incelendiğinde, liyakat ilkesinin bazı eksikleri ile birlikte kabul edildiği görülmektedir. Lakin liyakat ilkesi uygulamaya tam olarak yansıtılmamıştır. Aslında Türk kamu yönetimi liyakat ile kayırmacılık arasında bir yerde bulunmaktadır. Bu durum "siyasal kayırmacılığa da yer veren liyakat sistemi" olarak da adlandırılmaktadır (Yıldız, 2016: 156; Güven, 1976: 59; Uz, 2011: 86). $\mathrm{Bu}$ burum kamu yönetiminde kayırmacılığın varlığını devam ettirmesinin de temel nedenlerinden biridir.

Türkiye'de, valilik ve bakan yardımcılığg gibi sınırlı kadrolar dışında yasal olarak oluşturulmuş siyasi kadrolar bulunmamaktadır. Ancak uygulamaya bakıldığında yeterlilik ilkesinin varlığına rağmen, valilik ve bakan yardımcılığı gibi atamalarla sınırlı kalınmaksızın, daha alt kademelere doğru bir yönetim devrinin gerçekleştirildiği görülmektedir. $\mathrm{Bu}$ nedenle Türkiye'de siyasi partizanlık ve kayırmacılık yoğun bir şekilde görülmektedir. Bu durum ise kamu yönetiminin etkin ve verimli bir şekilde çalışmasına engel olan temel uygulamalardan biridir (Ergun, 2015: 297). 
Türk kamu yönetiminde siyasallaşma ve kayırmacılık başta yönetimde verimsizlik olmak üzere birçok sorunun yaşanmasına neden olmaktadır. Geniş kapsamlı bir sorun olması nedeniyle bu sorunun giderilebilmesi Türk kamu yönetimindeki birçok sorunun giderilmesine de yardımcı olacaktır. Çalışmanın bir sonraki başlığında siyasallaşma ve kayırmacılık sorunu Türk kamu yönetimindeki durumuna göre ahlak ve adalet temelinde incelenecek ve soruna çözüm aranmaya çalışılacaktır.

\section{KAMU YÖNETIMINDE SIYYASALLAŞMA VE KAYIRMACILIK SORUNUNUN GIDERILMESINDE AHLAK VE ADALETIN ROLÜ}

Türk kamu yönetiminde siyasallaşma ve kayırmacılık sorunu, ahlak ve adalet ile yakından ilişkili bir sorundur. Bu ilişki özellikle siyasallaşmanın neden olduğu sonuçlar açısından incelendiğinde daha da netleşmektedir. Kamu yönetiminde birçok siyasal davranıştan veya siyasallaşma sonucundan bahsetmek mümkündür. Öncelikle kamu yönetiminde siyasallaşma oy verenlere hizmet götürme, siyasi nitelikteki tayinler, kısa ve orta vadeli yatırımlar, ihalelerin belli kişi ya da gruplara verilmesi, kamu yönetiminin tarafsızlığının zedelenmesi ve üst düzey yöneticilerin sürekli değişimi sonucu istikrarsızlığın ve tutarsızlığın ortaya çıkması gibi birçok soruna neden sayılabilir (Dinçer, 1997: 1114). Yine yönetimin siyasallaşması, halk arasında ayrımcılığa ve kamu özgürlüklerinin kısıtlanmasına neden olabilmektedir. Kamu hizmetine girişte geçerli bulunan eşitlik ilkesi zedelenmekte, kamusal hizmetler objektifliğini yitirmekte, hükümet değişiklikleri sürecinde kamusal hizmetlerin sunumunda sürekliliği sağlamak zorlaşmakta, istenmeyen çalışanlar için keyfi uzaklaştırmalar ortaya çıkmakta ve yetenekli kişilerin yönetimden uzak tutulmaları söz konusu olmaktadır (Yılmaz ve Klavuz, 2002: 20; Tortop vd., 2010: 278-279).

$\mathrm{Bu}$ sonuçlar genel başlıklar altında incelendiğinde siyasallaşmanın kayırmacılığa, liyakatsizliğe, verimsizliğe, çıkarcılığa, keyfi uygulamalara ve kamu kaynaklarının siyasal iktidar için kullanılmasına neden olmaktadır. Bu sonuçların ahlak ve adalet açısından incelenmesi hem siyasallaşma ile kayırmacılığın ahlak ve adalet ile ilişkisinin hem de ahlak ve adaletin siyasallaşma ve kayırmacıllk sorununun giderilmesindeki öneminin daha rahat anlaşılmasını sağlayacaktır.

Temelinde hak ve vazife bulunan adalet, insanların sergiledikleri davranışların doğru olup olmadıklarını bizlere gösteren en önemli ilkedir. Doğruluk adaletin kişiselleşmesi ile ortaya çıkmaktadır. Davranışta ve eylemde doğru olmak adaletin sağlanması için temel bir görevdir (Çeçen, 1993: 64). Yani adalet, davranış ile vücut ve doğruluk bulmaktadır. Mevdudi'ye göre insan, mevkii ve konumu ne olursa olsun adaletten ayrılmamalıdır. Kimsenin kimseye hiçbir şekilde hiçbir kanuni imtiyazı yoktur. Adil kişi, daima haklı olana yönelen ve 
hakk1 gözeten kişidir (2016: 483-484). Bu durum ise doğruluğun ifadesidir. Bu nedenle kamu yönetiminde siyasallaşmanın neden olduğu kayırmacılığın engellenebilmesi için adaletli davranılmalı ve herkese karşı tarafsız bir şekilde hizmet sunulmalıdır. Tarafsızlık, kamu personelinin görevlerini yerine getirirken tüm vatandaşlara dil, din, felsefi inanç, siyasi düşünce, rrk ve cinsiyet ayrımı yapmadan hizmet sunmaları anlamına gelmektedir. Bu ilke çerçevesinde kamu görevlileri siyasi açıdan tarafsız davranırlar ve kamu makamlarının mevzuata uygun politikalarını, kararlarını veya eylemlerini engellemeye teşebbüs etmezler. Kamu görevlileri, tarafsızlık ilkesinin gereği olarak, herhangi bir siyasi parti, kişi veya zümrenin yararını ya da zararını hedef alacak bir davranışta bulunamazlar. $\mathrm{Bu}$ nedenle demokratik bir devlet vatandaşların hakları açısından tarafsız bir otorite olmak zorundadır (Yüksel, 2007: 584; Kalın, 2015: 104).

Gayri ahlaki ve adaletsiz bir davranış olarak kayırmacılık, "işe göre adam değil, adama göre iş" ayarlanmasını ifade etmektedir. Defterdar Sarı Mehmet Paşa, bu anlayışa karşı "her işin bir adamı vardır" ifadeleri ile ehliyetsiz kimselerin yüksek makamlara layık olmadıkları halde yakınların rica ve kayırması veya kendisine bağlılık ve yakınlığı olmak hasebiyle tayin yapılmaması gerektiğini ifade etmiştir (1969: 50).

Kayırmacılık konusunda adaletiyle tarihte ön plana çıkmış büyük devlet adamı Hz. Ömer'in (r.a.) uygulamaları günümüz kamu yönetimi açısından örnek niteliğindedir. Hz. Ömer (r.a.) bulunduğu makamı veya sahip olduğu yetkisini kayırmacılık adına kullanmamıştır. Öyle ki kendisine teklif edilmesine rağmen oğlu Abdullah'ı halifeliğe aday göstermemiş ve ne akrabalarını ne de yakınlarını iktidara taşımamaya özen göstermiştir. Hz. Ömer (r.a.) kamu görevlileri atamalarında toplumsal, kabilevi veya dini statülere göre değil, hak ve adalet ölçütlerini esas kriter olarak benimsemiştir. O bu konudaki hassasiyetini "Kim bir kişiyi sırf sevdiği veya akrabası olduğu için amil yaparsa, Allah'a, Resul'üne ve müminlere ihanet etmiş olur. Kim de kötü huylu birisini bile bile göreve getirirse, o da onun gibi özelliklere sahiptir." şeklinde ifade etmiş̧tir (Balcı, 2013: 86).

Erdoğan'a (1997: 981) göre Türkiye'de tarihsel bir olgu özelliği taşıyan ve halk kültürü içerisinde söylencelere kadar varan siyasal gücün kişisel çıkarlar için kullanılmasını engellemek kolay bir durum değildir. $\mathrm{Bu}$ nedenle kamu yönetiminde ve siyasal düzendeki çarpıklıkları aşmak için sadece bireysel ahlak yeterli değildir. Yani bu sorun, tek tek kişisel ahlaki zaaflardan değil, toplumsal bir ahlak eksikliğinden kaynaklanmaktadır. Platon (2016: 377) bu durumu insanlar ile devlet arasındaki ilişkiye dikkat çekerek açıklamaktadır. Ona göre insanlar nasılsa devlet de öyledir. Çünkü devlet, insani karakterlere göre şekillenmektedir. Yani kayırmacılığın önlenebilmesi için toplumsal bir ahlaki yetkinliğin oluşması gerekmektedir. 
Siyasallaşma açısından düşünüldüğünde siyasal kayırmacılık ile birlikte ortaya çıkan liyakatsizlik, gayri ahlaki ve adaletsiz bir davranış olarak, siyasal iktidarın kendisine destek veren kişileri kamu görevlerine atamaları ile ortaya çıkmaktadır. Oysa ahlaki davranış, yapılan atamalarda siyasi düşüncenin veya siyasal yakınlığın değil, liyakatin gözetilmesi ile somutlaşmaktadır. Bu durum adalet ile de yakından ilişkilidir. Kınalızade Ali Efendi adaletsizliği, "bir şeyi kendisine ait olmayan başka bir yere koymak" olarak ifade etmiştir (2016: 455). $\mathrm{Bu}$ bakış açısı ile adalet, "hak edenin hak ettiği yere getirilmesi" şeklinde tanımlanabilmektedir. Bu nedenle kamu yönetiminde siyasi iktidarın etkisi ile liyakate bakılmaksızın yapılan atamaların tümü hem gayri ahlaki hem de adaletsiz bir davranıştır.

Kamu görevlilerinin sürekli değişimi ile yönetimde istikrarın sağlanamaması ve dolayısıyla sürekli gelişen ve değişen toplumsal ihtiyaçların karşılanması mümkün değildir. Zira kamu yönetimi günümüzde daha karmaşık bir hal almış ve kamusal görevler birer uzmanlık alanı haline dönüşmüştür. Artık kamusal nitelikteki hizmetlerin sunumu herkes tarafından gerçekleştirilebilme niteliğini kaybetmiş ve mesleki tecrübe isteyen bir hal almıştır. Başka bir ifade ile kamu görevi siyasi iktidarın etkisi ile yeteneksiz, yetersiz ve taraflı hareket edilebilecek, yandaşlarla yürütülebilecek bir görev değildir (Uz, 2011: 74). Dolayısıyla kamu yönetimi, liyakat ilkesine karşı kayırmacılık ile yürütülebilecek bir kurum değildir.

Kamu yönetiminde siyasallaşma ve kayırmacılık çıkarcılığa da neden olabilmektedir. Çıkarcılık, kamu personelinin toplumsal fayda yerine kendi faydası için faaliyet göstermesinde ortaya çıkmaktadır. Siyasal partilere mensup kişiler siyasal nüfuz güçlerini kullanarak kamu personelinden bazı konularda ayrıcalıklı davranmasını isteyebilmekte ve kamu personeli de bu durumu kendisi için kullanabileceği bir kayırma imkanı elde etme olarak değerlendirebilmektedir (Özsemerci, 2003: 9). Bu durum kamu personelinin siyasallaşma aracıllğıyla bireysel veya siyasal çıkar elde etmesine neden olmaktadır. Toplumsal yarar yerine bireysel çıkarların ön planda tutulması hem kamu yönetiminin varlık nedenine aykırı hem de gayri ahlaki ve adaletsiz bir davranış olmaktadır. Kamu yönetiminin ahlaki olarak değerlendirilmesi onun varlık nedenine uygun davranması ile yakından ilişkilidir. Zira Kalın'a (2015: 104) göre devlet, hikmeti kendinden menkul bir kurum değildir ve mesuliyetini vatandaşa hizmetten almaktadır. Bu anlamı ile kamu görevlisinin temel ödevi vatandaşa hizmet etmektir. Platon da (2016: 35-36) yönetimde bulunan hiç kimsenin, bir yönetici olarak kalmaya devam ettiği sürece kendi çıkarlarına uygun olan şeyleri gözetmemesi, yönetilen kişilerin faydasına olan şeyleri gözetmesi ve yöneticinin konuştuğu ve yaptığ her işte bu amaca hizmet etmesi gerektiğini ifade etmiştir. Dolayısıyla devlet kadrolarının politika aracı olarak kullanılması önlenmeli ve vatandaşlara hizmet ön plana çıkarılmalıdır (Güzel, 1997: 139). 
Emek’e (2005: 6) göre kamu yönetiminde iyi bir yönetimin anahtarı, kamu görevlilerinin vatandaşlara karşı sorumluluklarını yerine getirmelerini sağlayacak ahlaki ilkelere uygun davranmaktır. Vatandaşların beklentilerine cevap vermek ve kamusal hizmetlerden yararlananların haklarına sahip çıkmak ve korumak kamusal ahlakın temel varlık nedenidir (Bayır, 2007: 17). Yine kurumsal çıkarları bireysel çıkarlardan üstün görmek ve kendi çıkarlarını yok saymak, hizmet aşk ile faaliyette bulunmak gibi değerler kamusal hayatta geçerli olan temel ahlaki ilkelerdir (Karasu, 2001: 245). Bu durum bireysel ahlak anlayışı ile de yakından ilişkilidir. Çünkü bireysel anlamda ahlaki yetkinliğe ulaşmış kamu personeli, bireysel çıkarlar yerine toplumsal çıkarları düşünecek ve kamu yönetiminin siyasallaşmasına engel olacaktır. Kamu yönetiminde bireysel çıkarlar yerine vatandaş beklentilerine uygun davranışların ön plana çıkarılması hususunda Osmanlı Devleti'nde, "bir fayda olunca önce halka, sonra yöneticilere; bir zarar olunca, önce yöneticilere sonra halka sor" şeklinde ifade edilmiştir. Bu ahlaki anlayış kamu personeline emanet olarak verilen kamu görevinin kendisi veya bir başka kişi adına menfaat aracı olarak kullanılmaması gerektiğini en güzel şekilde özetlemektedir (Dinçer, 1997: 1113).

Kamu yönetiminin bireysel çıkarlar doğrultusunda kullanılması aynı zamanda adalete de aykırıdır. Birçok anlama gelen adalet kavramı Ulpian'a göre dürüstçe yaşamaktır (Doğan, 2014: 113). Kamu yönetiminin toplumsal yarar yerine kişisel çıkarlar doğrultusunda kullanılması dürüstlüğe aykırı bir davranış olarak adaletsiz bir davranıştır. Adaletin olmazsa olmaz özelliği, kamu yönetiminin kendisinden bekleneni tam olarak yapmasında somutlaşmaktadır (Kılıç, 2014: 42). Dolayısıyla siyasallaşmanın neden olduğu çıkarcılığın önlenebilmesi hususunda kamu yönetiminde ahlak ile birlikte adaletin hakim kılınması olumlu sonuçlar doğuracaktır.

Siyasallaşma ve kayırmacıllğın bir diğer sonucu, kamu yönetiminde keyfi uygulamaların ortaya çıkmasıdır. Aslında kamu yönetimi faaliyetlerini başta anayasa olmak üzere kanun, tüzük, yönetmelik, yönerge, genelge vb. mevzuata uygun bir şekilde yerine getirmekle mükelleftirler. Ancak kamu yönetiminde var olan yasal düzenlemeler her zaman yeterli olmamaktadır ve tüm işlemlerin mevzuat doğrultusunda yapılması da mümkün değildir (Özdemir, 2008: 180; Kalabalık, 1999: 206). Bu nedenle kamu yönetiminde mevzuatın yetersiz kaldığı yerde kamu yöneticilerine takdir yetkisi verilmiştir. Kurallara kesin bağl1lı yerine takdir yetkisinin kabul edilebilir ölçülerde genişletilmesi, işlerin daha çabuk görülmesini sağlayabilir. Yani kamu düzenini korumak amaciyla genişletilen takdir hakkı devlet bürokrasinin etkisini arttıran bir araç olarak kullanılabilir. Ancak kamu hizmetinin etkin ve kesintisiz bir biçimde yürütülmesi endişesiyle tanınan takdir yetkisi tarafsız, dürüst ve bilgili kamu personelinin elinde olmadığı zaman olumsuz neticeler doğurabilir. $\mathrm{Bu}$ nedenle yönetimde kural dinlemezliğe ve keyfiliğe neden olabilecek boyutlarda kullanılmasına 
müsaade edilen takdir yetkisi, beklenenin tam tersi bir neticenin doğmasına yol açabilir. Yani takdir yetkisini kullanan kamu personeli bazı durumlarda siyasal iktidarın icracısı gibi faaliyet gösterebilir. Oysa kamu görevlileri, kamusal yararı gerçekleştirmek amacıyla tüm vatandaşlar adına yetkilerini kullanmaktadırlar. Dolayısıyla halk adına yetki kullanan personelin belli bir hizibin, grubun veya siyasi partinin bir mensubu gibi hareket etmemesi gerekmektedir (Özsemerci, 2005: 14; Erbay, 1997: 408). Aksi bir tutum kamu yönetiminin siyasallaşmasına zemin hazırlamaktadır. Kamu yönetiminde takdir yetkisinin siyasallaşma amaciyla kullanılmamasının engellenmesinde etkili olan temel unsurlar ahlak ve adalettir. Ergun'a (2015: 356) göre kamu personeli için ahlak, keyfi uygulamaların önüne set çeken en önemli ilkedir. Adaletin gözetilmediği kamu yönetiminde ise keyfi uygulamalar zulme neden olabilmektedir. Zira İbn Haldun (2011: 109), keyfi uygulamaların yönetimde zulme neden olabileceğini vurgulamıştır. Ahlak ve adaletin kamu personeli tarafından bir değer olarak benimsenmesi, yetkilerin kullanılmasında rasyonelliğin sağlanmasına yardımcı olacaktır.

Kamu yönetimindeki keyfi uygulamalar kamusal kaynakların siyasal iktidar için kullanılmasına da neden olabilmektedir. Erdoğan'a (1997: 161) göre Türkiye'de siyasal yozlaşmanın kamu yönetimi üzerindeki en önemli etkisi kamu otoritesinin ve kamusal kaynakların keyfi kullanılmasıdır. Platon'a göre keyfi davranışlarla işine geleni yapmak ahlaksızlıktır (2016: 46). Bu nedenle toplum adına kullanılması gereken kamusal kaynakların siyasal iktidarın amaçları doğrultusunda kullanılması gayri ahlaki bir durumdur. Çünkü bir makam için kullanılması gereken yetkiler ve kaynakların kamu görevlileri tarafından amaçları dışında veya siyasal amaçlar doğrultusunda kullanılması, görevin kötüye kullanılması anlamına gelmektedir. Ahlakın kamusal yaşamda tesisi, kamusal kaynakların kamu yararı doğrultusunda kullanılmasında etkili olacaktır.

Kamusal kaynakların kişisel menfaatler amacıyla kullanılabilmesinde liyakat ilkesi ön plana çıkmaktadır. Defterdar Sarı Mehmet Paşa, kamu görevinin liyakatsiz kişilere verilmesini kamusal kaynakların yağmalanmasına müsaade etmek olarak değerlendirmiştir (1969: 40). Bu durum aynı zamanda adaletin de göstergesidir. Zira Rousseau'ya göre adalet, vatandaşlar arasında ortak yararın gözetilmesidir (Kocaoğlu, 2014: 13). Bu nedenle kamusal kaynaklar bireysel veya siyasal menfaatler için değil, sadece ortak yarar için kullanılabilir.

Türk kamu yönetiminde siyasallaşma ve kayırmacılığın nedenlerinden bir diğeri, kamu yönetiminde gizlilik ve dışa kapalılığın hakim olmasıdır. Erdoğan'a (1997: 892) göre her türlü yozlaşmanın temelinde gizlilik bulunmaktadır. Siyasal yozlaşmanın bürokrasi üzerindeki etkisi de gizlilik perdesi altında çoğalmakta ve giderek toplumun tümünü kendi içine çekmektedir. Özellikle siyasallaşmanın kamu yönetimi içerisinde neden olduğu gayri ahlaki ve adaletsiz davranışlar 
gizlilikten dolayı var olmakta ve artmaktadır. $\mathrm{Bu}$ nedenle siyasallaşmanın engellenebilmesi için gizlilik ve dışa kapalılığın olağan sınırları içerisine çekilmesi ve şeffaflı̆̆ın ön plana çıkarılması gerekmektedir (Ergun, 1997: 393). Şeffaflığın sağlanması ise ahlakın ve adaletin gereğidir. Zira her iki kavram da aleni bir şekilde gerçekleştirilmesi gereken temel değerlerdir.

Kamu yönetiminde ahlakın en önemli özelliklerinden biri, toplumsal sorumluluk bilincinin yaygınlaşmanın sağlanmasıdır. Diğer bir ifadeyle, kamu görevlilerinin toplumsal sorumluluk bilinci içerisinde görevlerini ifa etmeleri gerekmektedir (Fındıkç1, 2013: 65). Sorumluluk ahlaki bir değer olarak adaleti gerekli kılmaktadır. Esasen insan olmanın en önemli gerekliliklerinden biri ahlaken, hukuken ve vicdanen sorumlu olmaktır (Akdemir, 2010: 92). Bu sorumluluklara sahip olan bir kamu görevlisi hayatının her alanında sahip olduğu hakları kullanırken adaletten ayrılamaz ve kamu yönetiminin amacı doğrultusunda faaliyet göstermesi için çalışır. Sorumluluk bilincinin zarar görmesi kamu yönetiminin siyasallaşmasına neden olmaktadır.

Türkiye'de kamu personelinin siyasal faaliyette bulunmaları sınırlandırılmıştır. Gerek kamu personelinin siyasal haklarının sınırlandırılmasının söz konusu olduğu ülkelerde, gerekse sınırlandırılmanın olmadığ1 ülkelerde geçerli olan temel kriter tarafsız ve nesnel bir kamu yönetiminin varlığıdır. Bu amacın sağlanabilmesi için; kamu personelinin siyasal partiler ile ilişkilerinin sınırlandırılması, parti üyeliğinin kamusal görevleri etkilememesi, kamu yönetiminin parti amaçları doğrultusunda kullanılmaması ve kamu yönetiminde yapılan atamaların ve yükselmelerin siyasal düşünceden bağımsız bir şekilde gerçekleştirilmesi gerekmektedir (Çiftçi, 1992: 107). Bu ilkelerin kamu yönetiminde gerçekleştirilmesi başta siyasallaşma ve kayırmacılığa engel olacaktır. Bu ilkeler aynı zamanda kamu yönetiminde gayri ahlaki ve adaletsiz davranışların ortaya çıkmasına engel olacaktır.

Kamu yönetimindeki yozlaşmış uygulamalar kamu yönetiminde ciddi prestij kaybına ve saygınlık zafiyeti yaşanmasına neden olmaktadır. Vatandaşlar nezdinde kamu yönetiminin güvenirliliği ve güvenilmezliği ahlaki davranışlar ile değerlendirilmektedir (Usta, 2012: 17). Bu nedenle, kamu görevlileri, halkın kamu hizmetine güven duygusunu zedeleyecek, şüphe yaratan ve adalet ilkesine zarar veren davranışlarda bulunmaktan kaçınarak güvenilir işlem ve eylemde bulunmalıdırlar (Yüksel, 2005 88).

Tüm bu söylemler 1şığında söylenebilir ki, siyasallaşma ve kayırmacıllı̆ıın engellenebilmesi için; kanunlar çerçevesinde ve vicdan ölçüsü içerisinde vatandaşa hizmet sunan memura, yükselişini siyasete veya siyasi davranışlara bağlamadan, görev aşkı ile hareket edip hizmetleri ile yükselen bürokrata, hizmette kayırmacılığ 1 değil, liyakati esas alan yöneticiye, devletin kendisine 
sunduğu imkanları ve yetkileri kendi kişisel menfaatlerine yahut ileride amaçladığ 1 siyasi faaliyetlere basamak yapmayan idareciye, görevi veya yetkisi gereği elde ettiği devlet sırlarını, basit ve haris amaçları için açığa çıkarmayan, bir takım vurgunlar için veya şantajlar için kullanmayan devlet görevlisine, haksızlıkla gönül yapma, siyasi pirim sağlama ve dolaylı da olsa menfaat temin etmek gibi davranışlarda bulunmayan (Keskin, 1997: 382) ve ahlaki erdemleri kendisinde barındıran insana ihtiyaç vardır.

Unutmamak gerekir ki siyasal iktidar ile bürokratlar, toplumsal anlamda kabul edilebilir bir ahlak ikliminin oluşturulmasında ve bu iklimin sürdürülmesinde gerekli ve öncelikli sorumlulukları üstlenmesi gereken kişilerdir. $\mathrm{Bu}$ sorumluluğun yeterince kavranmadığı ülkelerde yozlaşmanın neden olduğu sorunlar her zaman varlığını sürdürebilmekte ve hatta kurumsallaşabilmektedir (Ergun, 1997: 392). Bu nedenle her iki tarafın da bireysel çıkarları doğrultusunda birbirlerini etkilemeleri engellenmeli ve kamu yönetiminde ahlak ve adalet kültürünün oluşması için çaba sarf etmeleri gerekmektedir.

Türkiye'de kamu yönetiminde etik yönetim anlayışının oluşturulabilmesi ve ahlak ve adaletin kamu yönetimine hakim kılınabilmesi amacıyla çeşitli yasal düzenlemeler oluşturulmuştur. Bu düzenlemelerden doğrudan etik yönetim ile ilgili olanı 2004 yılında çıkarılan 5176 sayılı Kamu Görevlileri Etik Kurulu Kurulması ve Bazı Kanunlarda Değişiklik Yapılması Hakkındaki Kanunudur. Bu kanun doğrultusunda oluşturulan Kamu Görevlileri Etik Davranış İlkeleri İle Başvuru Usul Ve Esasları Hakkında Yönetmelik ile Kamu Görevlileri Etik Kurulu da oldukça önemli bir yere sahiptir. Dolayısıyla ilgili yasal düzenlemelerin ve Kamu Görevlileri Etik Kurulunun hem kamu yönetiminde genel anlamda etik yönetim anlayışı üzerindeki etkisinin hem de özelde kamu yönetiminde siyasallaşma ve kayırmacılık sorununun giderilmesi konusundaki rolünün incelenmesinde fayda vardır.

\section{Kamu Görevlileri Etik Kurulu ve Kurulun Siyasallaşma ve Kayırmacılığı Önlemedeki Etkisi}

Türk kamu yönetiminde, yönetime ahlak ve adaletin hakim k1lınabilmesi amacıyla oluşturulan en önemli düzenleme hiç şüphesiz 2004 yılında çıkarılan 5176 sayılı Kamu Görevlileri Etik Kurulu Kurulması ve Bazı Kanunlarda Değişiklik Yapılması Hakkındaki Kanunudur. 5176 sayılı kanuna kadar Türk kamu yönetiminde ahlak ile ilgili düzenlemeler dağınık halde bulunmaktaydı. $\mathrm{Bu}$ yasa ile Türkiye'de doğrudan etik yönetime yönelik bir çalışmanın bulunması, Türk kamu yönetiminde ahlakın hakim k1lınabilmesi için ciddi bir önem arz etmektedir. Çünkü bu yasa ile ahlak konusu bireysel veya toplumsal zeminden sonra ilk defa yasal zeminde kendisine yer bulmuştur (Koçak ve Yüksel, 2010: 82). 5176 sayılı yasanın temel amacını belirten 1. madde "kamu görevlilerinin 
uymaları gereken saydamlık, tarafsızlık, dürüstlük, hesap verebilirlik, kamu yararını gözetme gibi etik davranış ilkeleri belirlemek ve uygulamayı gözetmek üzere Kamu Görevlileri Etik Kurulunun kuruluş, görev ve çalışma usul ve esaslarının belirlenmesi” şeklindedir. Yasanın amacını oluşturan bu madde kamu yönetiminde özellikle etik davranış kodlarının belirlenmesi ve ahlaki bir kültürün kamu yönetimine hakim kılınmasını öngörmektedir.

Yasanın çıkarılmasının temel nedeni her ne kadar yasada açıça belirtilmese de kamu yönetiminin dayandığı temel değerler ve standartlarındaki düşme ve buna bağlı olarak ortaya çıkan prestij kaybıdır. Yine vatandaşların kamu yönetimine karşı güvenlerinin azalması, kamu yönetiminden daha kaliteli hizmet beklentilerinin artması, iyi yönetişim anlayışının kamu yönetiminde bir dönüşümü zorunlu kılması gibi nedenler etik anlayışın kamu yönetimi tarafından dikkate alınmasını zorunlu kılmıştır (Demirci ve Genç, 2008: 50-51).

5176 sayılı Kamu Görevlileri Etik Kurulu Kurulması ve Bazı Kanunlarda Değişiklik Yapılması Hakkındaki Kanun doğrultusunda oluşturulan Kamu Görevlileri Etik Davranış İlkeleri İle Başvuru Usul Ve Esasları Hakkında Yönetmelik kamu yönetimine ahlak ve adaletin hakim kılınması amacını taşıyan oldukça önemli bir yönetmeliktir. Yönetmeliğin belirlemiş olduğu temel etik ilkeler, kamu görevlilerinin halka hizmet bilinci ile faaliyet göstermeleri, hizmetlerin gerektirdiği standartlara uyma, kamu kurum ve kuruluşlarının amaç ve misyonlarına bağlı kalma, görevlerin dürüst ve tarafsız bir şekilde yerine getirilmesi, görevin gerektirdiği itibar ve güvene layık davranma, kurumun iç ve dış hedef kitlesine karşı nezaket ve saygıyı gözetme, çıkar çatışmasından kaçınma, görev ve yetkilerin menfaat sağlamak amacıyla kullanılmaması, hediye alma yasağı, kamu kaynaklarının ve mallarının korunması, savurganlıktan kaçınma, şeffaf bir yönetimin oluşturma, yönetime katılım, hesap verebilirlik ve mal bildiriminde bulunma olarak belirlenmiştir. Bu ilkeler kamu yönetiminde etik kültürün hakim kılınması amacıyla belirlenmiş temel yönetsel etik ilkelerdir.

Kamu Görevlileri Etik Davranış İlkeleri İle Başvuru Usul Ve Esasları Hakkında Yönetmelik siyasallaşma ve kayırmacılık açısından incelendiğinde, ilgili yönetmeliğin 14. maddesi "Kamu görevlileri; görev, unvan ve yetkilerini kullanarak kendileri, yakınları veya üçüncü kişiler lehine menfaat sağlayamaz ve aracılıkta bulunamazlar, akraba, eş, dost ve hemşehri kayırmacılığı, siyasal kayırmacılık veya herhangi bir nedenle ayrımcılık veya kayırmacılık yapamazlar" ifadelerine yer vermektedi. İlgili madde, hem kayırmacılık hem de siyasallaşma ile ortaya çıkabilecek kayırmacılığın engellenmesi açısından oldukça önemlidir.

Gerek 5176 sayılı yasa gerekse bu yasa doğrultusunda oluşturulan yönetmelik incelendiğinde, her iki düzenlemenin de temelde kamu yönetiminde gayri ahlaki 
ve adaletsiz davranışları önlemek, kamu görevlilerinin uymaları gereken ahlaki ilkeleri belirlemek ve kamu yönetiminde etik kültürünün yerleşmesini sağlamak gibi amaçlar doğrultusunda çıkarıldığı görülmektedir. Ancak uygulamada ortaya çıkan aksaklıklardan dolayı hem yasanın hem de ilgili yönetmeliğin tam anlamı ile uygulandığını söylemek mümkün değildir.

5176 sayılı Kanunun 1. maddesi doğrultusunda Kamu Görevlileri Etik Kurulunun oluşturulması amaçlanmıştır. 2004 yılında 5176 sayılı Kanun kapsamında Kamu Görevlileri Etik Kurulu kurulmuş ve kanunun 3. maddesi gereğince kamu personelinin görevlerini icra ederken uyması gereken ilkeler hakkında yönetmeliğin çıkarılması, etik davranış kodlarının ihlali iddiası ile kendiliğinden veya başvuru üzerine gerekli incelemeleri araştırmak, ilgili yerlere bildirmek ve kamu yönetiminde ahlakın yerleşmesi için çalışmalar yapmak veya yaptırmak ile görevlendirilmiştir. Kanun gereği Kurul, "Genel Müdür" düzeyindeki yöneticilerin başvurularını kabul etmektedir. Diğer kamu görevlilerinin başvuruları ise Kurulda incelendikten sonra değerlendirilmektedir. Kurul başvuru sonrasında gerekli gördüğü bilgileri bakanlıklardan veya diğer kamu kurumlarından istemektedir. Kurulun istediği bilgiler kendisine verilmek zorundadır. Soruşturma en geç üç ay içerisinde son bulmakta ve sonuç Cumhurbaşkanlığı ve Çalışma, Sosyal Hizmetler ve Aile Bakanlığına yazılı olarak bildirilmektedir.

Kamu Görevlileri Etik Kurulu Türkiye'de hem etik yönetim anlayışının yasal temelde ele alınması hem de kamu yönetimindeki gayri ahlaki davranışların engellenmeye çalışılması açısından oldukça önemli bir yeniliktir. Ancak Kamu Görevlileri Etik Kurulu oluşturulduktan sonra zaman içerisinde ortaya çıkan bazı gelişmeler bir takım sorunları beraberinde getirmiştir. Bu durum 5176 sayılı yasaya bazı eleştirilerin getirilmesi sonucunu doğurmuştur. Özellikle yasanın 1. maddesinin son fikrasında yer alan "Cumhurbaşkanı, Türkiye Büyük Millet Meclisi üyeleri, Cumhurbaşkanı Yardımcıları ve Bakanlar, Türk Silahlı Kuvvetleri ve yarg1 mensupları ve üniversiteler hakkında bu Kanun hükümleri uygulanmaz" ibaresi yasanın büyük bir eksiği olarak ifade edilmektedir (Koçak ve Yüksel, 2010: 80). Çünkü Türkiye’deki tüm kamu görevlilerini kapsamayan bir etik kurulun varlığı Kurulun etki derecesini azaltmaktadır. Ayrıca siyasi nitelikteki kişilerin veya kuruluş üyelerinin yasa kapsamı dışında bırakılması Türkiye'de siyasallaşma hususunda oldukça önemli bir sorunu ortaya çıarabilmektedir. Yine Kurul etik ihlal kararlarının Resmi Gazete'de yayınlanmasına ilişkin 5176 sayılı Kanun'un 5. maddesinin 3. fikrasının Anayasa Mahkemesi'nin 4/2/2010 tarihli ve E.:2007/98, K.:2010/33 sayıl1 Kararı ile iptal edilmesinden sonra yeni bir düzenleme yapılmaması Kurulun etkisini azaltmıştır. Yeni haliyle Kurul kararları yaptırımdan uzak ve sadece bir tespitten ibaret olup kamu görevlilerini caydırıcı, doğrudan ilgili eylem ve işlemi önleyici bir nitelikte değildir. $\mathrm{Bu}$ durum Kurulun istenilen işlevselliğe ulaşmasını engellemektedir. 
Kurulun istenilen etkinliğe ve işlevselliğe ulaşmaması ise kamu yönetiminde etik alanında istenilen değişim ve dönüşümün gerçekleştirilmesini zorlaştırmaktadır (Akdeniz, 2016: 65-80).

5176 sayılı yasa ile etik mevzuatın temelleri atılmış olmasına rağmen hem ilgili yasal düzenlemelerde bir takım eksiklerin olduğu hem de Kamu Görevlileri Etik Kurulunun yapısal ve işlevsel sorunlarının devam ettiği söylenebilir. Kurulun faaliyet ve denetim alanının oldukça kısıtlı olması ve Kurulun faaliyet alanına giren birçok konunun mevzuatımızda düzenlenmiş olması, Kurulun etkinliğinin ve kamu yönetimi açısından kabul edilebilirliğinin sorgulanmasına neden olmaktadır (Usta ve Arslan, 2020: 237-238).

Kamu Görevlileri Etik Kurulunun siyasi iktidardan bağımsız bir şekilde faaliyet gösterdiğini söylemek de oldukça güçtür. Kurulun siyasi iktidarla çatışması durumunda işlevselliği azalacaktır. İktidarın olası taleplerini dikkate alma durumunda ise kimi konuları görmezden gelebilme riski ortaya çıkacaktır. Etik davranışlara uygun hareket edilmesinin sağlanması düşüncesi ile oluşturulan Kurulun siyasal organları denetim dışında bırakması, Kurulun simgesel bir hal almasına neden olmaktadır. Bu durum Kurulu büyük sorumluluklar üstlenen ancak güçsüz bir kurum olarak faaliyet gösteren bir yapı hale getirmiştir (Arap ve Y1lmaz, 2006: 66).

Kamu Görevlileri Etik Kurulunun kamu yönetiminde etik yönetim anlayışının oluşturulması hususunda tek başına yeterli olmadığı düşünülmektedir. Kamu yönetiminde etik kültürü yerleştirmek ve eşitlik, adalet, hesap verebilirlik, şeffaflık gibi ilkelere dayalı bir kültürel altyapının kurumsallaştırılması kamu, özel ve sivil toplum kuruluşlarının ortak işbirliğine dayalı gerçekleştirilebilecek bir durumdur (Altun vd., 2013: 53). Aksi bir anlayış gayri ahlaki davranışların ve adaletsizliğin kamu yönetiminde var olmasına neden olacaktır. Bu durum kamu yönetiminde siyasallaşma ve kayırmacılık sorununun varlığını devam ettirmesini de beraberinde getirecektir.

Kamu Görevlileri Etik Kurulu kamu yönetiminde siyasallaşma ve kayırmacılık sorununun giderilmesinde etkili bir şekilde faaliyet gösteren bir Kurul olmaktan uzaktır. Hem Kurulun işlevselliğinin kısıtlı olması hem de Kurulun dayandığ 5176 sayılı yasanın kendi içerisinde barındırdığ kamu yönetiminde siyasallaşma ve kayırmacılık sorununun varlığını devam ettirmesine neden olmaktadır. Bu konuda yapılması gereken öncelikli iş ilgili eksikliklerin giderilerek Kurula işlevsellik kazandırılmasıdır. $\mathrm{Bu}$ hususta yapılması gerekenler şu şekilde sıralanabilir (Usta ve Arslan, 2020: 239-240):

5176 say1lı yasada ve bu yasa doğrultusunda oluşturulan yönetmelikte etik kavramı ve etik ilkeler ile ilgili tanımlar net bir şekilde yapılmalı ve etik ilkeler daha somut bir şekilde ortaya konmalıdır. 
Etik yönetim ile ilgili yasal alt yapı kamu yönetiminin tüm kurumlarında uygulanabilecek şekilde ve kapsamda tekrar düzenlenmelidir.

Etik davranış kurallarını uygulama hususunda daha etkin bir uygulama mekanizması geliştirilmelidir.

5176 sayılı yasa doğrultusunda oluşturulan Kamu Görevlileri Etik Kuruluna etik ilkeleri belirleme işlevinin yanı sıra etik ilkelerin davranışa dönüştürülmesi hususunda da daha etkin bir uygulama alanı sağlanmalıdır.

Kamu Görevlileri Etik Kurulunun siyasileri de kapsayacak şekilde faaliyet göstermesi veya siyasi etik yasasının çıkarılması gerekmektedir

Kurulun faaliyet alanının genişletilmesi ve aldığı kararların etkinliğinin arttırılması gerekmektedir.

Kurulun tanınırlığını arttırmak için yapılan çalışmalara daha fazla önem verilmelidir.

Etik kurulun bağımsız ve tarafsız bir yapıya dönüştürülebilmesi için gerekli yasal düzenlemeler yapılmalı ve Kurul üyelerinin seçimi TBMM'ne birakılmalidır.

Kurul bünyesinde faaliyet gösteren etik komisyonların tekrardan yapılandırılması ve işlevselliğinin arttırılması gerekmektedir.

İhbarcılık mekanizması geliştirilmeli ve ihbarcılık teşvik edilmelidir.

Kamu yönetiminde etik eğitimi yaygınlaştırılmalıdır.

Etik ilke ve değerlerin toplumsal düzeyde arttırılması için gerekli çalışmalar yapılmalı ve etik kültürün oluşturulması noktasında etik liderlik teşvik edilmelidir.

Kamu yönetiminde siyasallaşma ve kayırmacılık sorunu, yönetimde görülen birçok etik sorun ile benzer sonuçlara neden olmaktadır. Siyasallaşma ve kayırmacılık sorunu vatandaşlar adına ve kamu yararına hizmet yürütmesi gereken kamu yönetiminin belirli bir kişiye veya gruba hizmet etmesine neden olmaktadır. Türkiye'de etik yönetim ile ilgili yasal düzenlemelerin olgunlaştırılması ve var olan yasal problemlerin giderilmesi kamu yönetiminde gayri ahlaki ve adaletsiz davranışların yaşanmasını önemli ölçüde azaltacaktır. Kamu Görevlileri Etik Kurulu, bu amaç ile kurulmuş fakat etkinliği henüz sağlanamamış oldukça önemli bir Kuruldur. Kurulun etkinliğine ve işlevselliğine yönelik sorunlarının giderilmesi hem kamu yönetiminde etik yönetim kültürünün 
oluşmasını hem de siyasallaşma ve kayırmacılık adı altında yaşanan gayri ahlaki ve adaletsiz davranışların engellenmesini sağlayacaktır.

\section{SONUÇ}

Siyasallaşma ve kayırmacılık sorunu ahlak ve adalet ile yakından ilişkili ve sonuçları bakımından ahlak ve adalete aykırı bir sorundur. Çünkü siyasallaşma sorunu genel başlıkları ile kayırmacılığa, liyakatsizliğe, verimsizliğe, çıkarcılığa, keyfi uygulamalara ve kamusal kaynakların siyasal otoriteler için kullanılmasına neden olmaktadir.

Gayri ahlaki ve adaletsiz bir sorun ve sonuç olan kayırmacılık, kamu yönetiminin başarısını doğrudan etkileyen temel bir problemdir. Öncelikle kayırmacılık, işe alımlarda ve kamusal faaliyetlerde liyakat ilkesini ihlal ettiği için adaletsiz ve gayri ahlaki bir davranıştır. Bu durum kamu yönetiminin verimsizleşmesine de neden olan temel bir etkendir. Zira adaletin ve ahlakın göz ardı edildiği ve yerine siyasallaşmanın ve kayırmacılığın ön plana çıkarıldığı bir yönetimde personelin başarılı olması beklenemez. Oysa adalet tüm kamusal faaliyetlerde her kim neyi hak ediyorsa onun kendisine verilmesini gerekli kılmaktadır. Dolayısıyla Türk kamu yönetiminde kayırmacılığın engellenebilmesi için atılması gereken temel adım liyakat sistemine işlerlik kazandırılarak ahlak ve adaletin hakim kılınmasıdır.

Siyasallaşma ve kayırmacılık kamu yönetiminde çıkarcıllı̆g neden olabilmektedir. Çıkarcılık kamu personelinin kamusal kaynakları toplum yerine kendi adına kullanmasına neden olmaktadır. Kamu yönetiminin varlık nedenine aykırı olan bu durumun giderilebilmesi ahlak ve adaleti gerekli kılmaktadır. Çünkü ahlak ve adalet, herhangi bir şeyin amacı doğrultusunda kullanılmasının yegane yoludur.

Siyasallaşma ve kayırmacılık ile kamu yönetiminde keyfi uygulamalar baş göstermektedir. Aslında Türkiye'de kamu personeli görev ve yetkilerin yasalara, tüzüklere, yönetmeliklere vs. dayanarak kullanmaktadır. Ayrıca kamu yönetiminde etik sorunların giderilmesi ve etik kültürün kamu yönetimine hakim k1lınabilmesi amaciyla 2004 yılında çıkarılan 5176 sayılı yasa ve bu yasa kapsamında oluşturulan Kamu Görevlileri Etik Kurulu oldukça önemli düzenlemelerdir. Ancak 5176 sayılı yasanın kendi içerisinde birçok eksikliği barındırması, Kamu Görevlileri Etik Kurulunun yeteri düzeyde etkin ve işlevsel bir şekilde faaliyet gösterememesi gibi nedenler kamu yönetiminde siyasallaşma ve kayırmacılık gibi gayri ahlaki ve adaletsiz etik ihlallerin yaşanmasını beraberinde getirmektedir. Ayrıca kamu yönetiminde tüm işlerin kanunlar çerçevesinde yapılmasının mümkün olmaması ve tüm işlemlerin yasalar çerçevesinde yapılmasının kırtasiyeciliğe neden olmasından dolayı takdir yetkisi bulunmaktadır. İşte bu noktada siyasallaşmış kamu yönetimi keyfi uygulamalara 
maruz kalabilmektedir. Bu durumun sonucu olarak kamu personeli kamusal kaynakları kendi hesabına kullanabileceği gibi siyasal iktidar yararına da kullanabilmektedir. Oysa ahlak ve adalet kamusal kaynakların bireysel veya siyasal çıkarlar doğrultusunda değil, kamu yararı için kullanılmasını ön görmektedir.

Sonuç olarak ifade edilebilir ki ahlak ve adalet, siyasallaşma ve kayırmacılık sorunu ile bu sorunun ortaya çıkardığ tüm olumsuz sonuçların giderilmesinde doğrudan etkilidir. Özellikle sonuçları itibariyle kamu yönetiminde olumsuz uygulamaların yaşanmasına ve kamu yönetiminin amacı doğrultusunda faaliyet göstermesine engel olan siyasallaşma ve kayırmacılık sorunu, ideal bir kamu yönetimi için gerekli olan tüm değerleri ifade eden ahlak ve adalet ile aşılabilir. Dolayısıyla ahlak ve adaletin kamu yönetiminde varlığının etkin kılınması gerekmektedir.

\section{KAYNAKÇA}

Akdemir, F. (2010). Lockecu perspektiften temel hak ve özgürlüklerin kaynağ ve güvencesi üzerine bir analiz. Birinci uluslararası felsefe kongresi bildiriler kitab1, 92-97.

Akdeniz, İ. (2016). Kamu görevlileri etik kurulunu yeniden düşünmek. Sayıştay Dergisi, 103, 59-83.

Aktan, C. C. (2001). Siyasal ahlak ve siyasal yozlaşma. İçinde C. C. Aktan (Ed.), Yolsuzlukla Mücadele Stratejileri (ss.51-69), Hak-İş Yayınları.

Altun, M., Sayer, A. ve Barutçu, A. (2013). Kamu görevlileri etik kurulu kararları 1şığında kamuda görülen etik dışı davranışlar ve yolsuzluklar. Sayıştay Dergisi, 91, 33-55.

Arap, İ. ve Yılmaz, L. (2006). Yeni kamu yönetimi anlayışının “yeni” kurumu: Kamu görevlileri etik kurulu. Amme İdaresi Dergisi, 69(2), 51-69.

Aydın, A. H. (2017). Türk kamu yönetimi. Seçkin Yayıncılık.

Balcı, İ. (2013). Hak ve adaletle taçlandırılan bir idari portre: Hz. Ömer. Din ve Hayat Dergisi, 18, 84-90.

Bayır, M. Ö. (2007). Türkiye'de etik-yansızlık-katılım boyutları açısından bürokrasi ve siyaset ilişkisi. [Yayımlanmamış Yüksek Lisans Tezi], Mersin Üniversitesi.

Berkman, A. Ü. (2009). Gelişmekte olan ülkelerde kamu yönetiminde yolsuzluk ve rüşvet. TODAİE Yayınları. 
Çeçen, A. (1993). Adalet kavramı. Gündoğan Yayınları.

Çevik, H. H. (2012). Kamu yönetimi. Seçkin Yayıncılık.

Çiftçi, O. (1992). Siyasal haklar ve kamu görevlileri. İçinde M. Gülmez (Ed.), Insan Hakları ve Kaтu Görevlileri Sempozyumu Bildiriler Kitabı (ss. 89126). TODAİE Yayınları.

Defterdar Sarı M. P. (1969). Nesayih'ül Vüzera V'el Ümera. (H. R. Uğural, Çev.), Türk Tarih Kurumu Basımevi.

Demirci, M. ve Genç, F. N.l (2008). Türkiye’de kamu yönetimi reform sürecinde etik yapılanma. Amme İdaresi Dergisi, 41(2), 43-58.

Dinçer, Ö. (1997). Kamu yönetiminde davranışların siyasallaşması ve yolsuzluk. Yeni Türkiye Dergisi, 14, 1112-1118.

Doğan, S. (2014). Uygarlık merkezli ahlak ve adalet eğitimi yaklaşımı. Bitlis Eren Üniversitesi Sosyal Bilimler Enstitüsü Dergisi, 3(1), 111-126.

Emek, U. (2005). Kamu yönetiminde yeniden yapılanmanın etik temelleri. Y1ldız Teknik Üniversitesi Sosyal Bilimler Enstitüsü, Friedrich-Ebert Vakfı ve Türkiye Etik Değerleri Merkezi (TEDMER) ile Ortaklaşa Olarak Düzenlenen Çalıştay, ss. 5-59.

Erbay, Y. (1997). Bürokrasi, Bürokratizm ve Ülkemizde Bürokrat-Siyasetçi İlişkileri. Yeni Türkiye Dergisi, 13, 405-412.

Erdoğan, R. T. (1997). Kapalı toplum-açık toplum ekseninde siyasal yozlaşma. Yeni Türkiye Dergisi, 14, 981-982.

Ergun, T. (1997). Kamu yönetiminde yolsuzluklar ve bürokrasinin sorumluluğu. Yeni Türkiye Dergisi, 13, 388-393.

Ergun, T. (2015). Kamu yönetimi kuram, siyasa, uygulama. TODAİE Yayını.

Ery1lmaz, B. (1997). Bürokrasi ve iktidar. Yeni Türkiye Dergisi, (14), 1356-1365.

Eryılmaz, B. (2007). Parlamento-Bürokrasi İlişsilerinin Çeşitli Boyutları. İçinde B. Eryılmaz, M. Eken ve M. L. Şen (Ed.), Kamu Yönetimi Yazıları (ss. 246-257) Nobel Yayınları.

Eryılmaz, B. (2015). Kamu yönetimi. Umuttepe Yayınları.

Fındıkçı, L. (2013). Yerel yönetimler etik ve patronaj. Uluslararası Hakemli Beşeri ve Akademik Bilimler Dergisi, 2(4), 62-87. 
Gökçe, G., Şahin, A. ve Örselli, E. (2002). Türkiye'de siyasetin bürokrasi üzerindeki etkisi: siyasallaşma. Selçuk Üniversitesi İktisadi ve İdari Bilimler Fakültesi Sosyal ve Ekonomik Araştırmalar Dergisi, 4, 45-58.

Gökçe, O. ve Şahin, A. (2002). 21. Yüzyılda Türk bürokrasisinin sorunları ve çözüm önerileri. Selçuk Üniversitesi İktisadi ve İdari Bilimler Fakültesi Sosyal ve Ekonomik Araştırmalar Dergisi, 3, 1-27.

Güven, H. S. (1976). İdare siyaset ilişkileri ve personel yönetimi açısından önemi. Amme İdaresi Dergisi, 9(1), 50-70.

Güzel, H. C. (1997). Siyasette yeniden yapılanma. Yeni Türkiye Dergisi, 13, 235240.

İbn H. (2011). Mukaddime I-II. (S. Uludağ, Çev.) Dergah Yayınları.

İzci, F. ve Bozdoğan S. (2016). Türk kamu yönetiminde bir problem alanı olarak bürokrasi-siyaset ilişkisi. Akademik Sosyal Araştırmalar Dergisi, 34, 3346.

Kalabalık, H. (1999). İdare hukukunda takdir yetkisi kavramı ve benzer kurumlarla karşılaştırılması. Gazi Üniversitesi Hukuk Fakültesi Dergisi, 1(2), 205-232.

Kalın, İ. (2015). Akll ve erdem. Küre Yayınları.

Karakuş, M. ve Çak, M. (2007). Yolsuzlukla mücadelede uluslararası kuruluşların rolü. Maliye Dergisi, 153, 74-101.

Karasu, K. (2001). Profesyonelleşme olgusu ve kamu yönetimi. Mülkiyeler Birliği Vakfi Yayınları.

Keskin, O. K. (1997). Siyasette değil cemiyette yozlaşma. Yeni Türkiye Dergisi, 13, 381-383.

Kılıç, H. (2014). Adalet: Güç savaşında denge noktası. Beta Yayınları.

Kınalızade A. Ç. (2016). Ahlak-ı Alai, (M. Demirkol, Çev.). Fecr Yayınları.

Kocaoğlu, M. (2014), Robert Nozick: Adalet teorisi ve temel kavramlart. İmaj Yayınevi.

Koçak, S. Y. ve Yüksel, G. (2010). Türk kamu yönetiminde etik ve kamu görevlileri etik kurulu. Bilgi Dergisi, 21, 73-95.

Mevdudi (2016). İslam'da hükümet. (A. Gencer, Çev.), Hilal Yayınları. 
Özdemir, M. (2008). Kamu yönetiminde etik. Zonguldak Karaelmas Üniversitesi Sosyal Bilimler Dergisi, 4(7), 179-195.

Özer, M. A. (2000). Türkiye’de kamu bürokrasisi ve yozlaşma. Sayıştay Dergisi, $37,75-113$.

Özkanan, A. ve Erdem, R. (2014). Yönetimde kayırmacı uygulamalar: Kavramsal bir çerçeve. Süleyman Demirel Üniversitesi Sosyal Bilimler Enstitüsü Dergisi, 20, 179-206.

Özsemerci, K. (2003). Türk kamu yönetiminde yolsuzluklar, nedenleri, zararları ve çözüm önerileri. T.C. Sayıştay Başkanlığı Yayını.

Özsemerci, K. (2005). Türk kamu yönetiminde yolsuzluk ve yozlaşmanın kültürel altyapısı. Sayıştay Dergisi, 58, 1-20.

Platon (2016). Devlet. (E. Alagöz, Çev.), Panama Yayınları.

Sakl1, A. R. (2011). Disiplinler arası bir disiplin olarak kamu yönetimi. Gazi Üniversitesi İktisadi ve İdari Bilimler Fakültesi Dergisi, 13(2), 97-120.

Tortop, N., İsbir, E. G., Aykaç, B., Yayman, H. ve Özer, M. A. (2010). Yönetim bilimi. Nobel Yayınları.

Tutum, C. (1976). Yönetimin siyasallaşması ve partizanlık. Amme İdaresi Dergisi, 9(4), 9-32.

Usta, A. (2012). Etik ve ahlak teorilerinin kamu yönetimine uygulanabilirliği, H. Kavruk (Ed.), KAYFOR IX Bildiriler Kitabı (ss. 15-32). TODAİE Yayını.

Usta, S. ve Arslan, Ş. (2020). Türkiye'de etik yönetim anlayışına yönelik çerçeve arayışı: Kamu görevlileri etik kurulu üzerinden bir inceleme. Akademik Yaklaşımlar Dergisi, 11(2), 222-244.

Uz, A. (2011). Anayasal bir kavram olarak kamu hizmetine girme hakk1 ve liyakat ilkesi. İnönü Üniversitesi Hukuk Fakültesi Dergisi, 2(1), 59-94.

Yazıcıoğlu, R. (1997). Türkiye nereye gidiyor? İdari ve siyasi yozlaşma. Yeni Türkiye Dergisi, 13, 254-264.

Yıldız, G. (2016). Türk kamu yönetiminde liyakat ilkesi. Gazi Üniversitesi Sosyal Bilimler Dergisi, 3(8), 140-180. 
Yılmaz, A. ve Kılavuz, R. (2002). Türk kamu bürokrasisinin işlemsel sorunları üzerine notlar. Cumhuriyet Üniversitesi İktisadi ve İdari Bilimler Fakültesi Dergisi, 3(2), 17-31.

Yüksel, C. (2005). Devlette etikten etik devlete: Kamu yönetiminde etikkavramsal çerçeve ve uluslararası uygulamalar I. Türk Sanayicileri ve İş Adamları Derneği Yayını.

Yüksel, C. (2007). Kamu yönetiminde etik davranış kuralları. İçinde B. Eryılmaz, M. Eken ve M. L. Şen (Ed.), Kamu Yönetimi Yazıları (ss. 582-606), Nobel Yayınları. 